Elżbieta Kukuła, Aleksandra Piskorska

Uniwersytet Warszawski

\title{
Przygotowanie nauczycieli do korzystania z sieci w nauczaniu sztuki (sztuka w sieci - aspekty edukacyjne)
}

\begin{abstract}
Kilka sekund ma nowy wynalazek na to, aby nas zainteresować. I już pojawia się następny. Kilka sekund ma nowa technologia, aby przykuć uwage. Jeśli $w$ ogóle jeszcze sformułowanie "przykuwanie uwagi" ma sens [...] wszystko, co poznaliśmy dotąd, już nie działa (Eryk Mistewicz)
\end{abstract}

\section{Wstęp}

Zmiany kulturowe i społeczne w ostatnich latach przyczyniły się do dynamicznego rozwoju sztuki w zakresie multimedialnym. Nastąpiło przeniesienie wszystkich jej właściwości do nowej rzeczywistości, do nowego środowiska odbiorców, sztuka stała się dyspozycyjna, otwarta na nowe możliwości i nowe technologie.

Umiejętność ustosunkowania się do różnych form ekspresji i przekazu sztuki jest niezbędna do jej zrozumienia oraz pełnego uczestnictwa jednostki w kulturze. Aby móc jednak mówić o uczestnictwie w kulturze i o samym poszerzaniu wiedzy o sztuce, trzeba zacząć od przygotowania nauczyciela, który ma przekazywać tę wiedzę. Jego zadaniem w zakresie samokształcenia powinna być stała aktualizacja swojej wiedzy, poszerzanie horyzontów, a także posiadanie odpowiednich cech osobowych, wychowawczych, a także dydaktycznych, o których pisze Czesław Banach ${ }^{1}$, są to m.in. aktualna wiedza merytoryczna w zakresie nauczanej dziedziny, właściwe przygotowanie pedagogiczno-psychologiczne, twórczość, postępowość, odwaga, a także różnorodność stosowanych metod i środków nauczania, od których zależy efektywność i atrakcyjność prowadzonych zajęć. Tego m.in. dotyczy

\footnotetext{
${ }^{1}$ C. Banach, Cechy osobowościowe nauczyciela, „Nowa Szkoła” 1995, nr 3.
} 
poniższe opracowanie - stanowi ono przedstawienie zagadnień i doświadczeń wyniesionych z kilkuletniej pracy ze studentami na platformie multimedialnej Moodle COME.UW².

\section{Społeczeństwo medialne a cyfrowa szkoła}

Powstające na naszych oczach społeczeństwo medialne ${ }^{3}$ stawia przed nauczycielem nowe wyzwania. Uczniowie, studenci z coraz większą intensywnością „wykorzystują media techniczne pokonujące czas i/lub przestrzeń [...]. Miejsce Face-to-Face zajmuje kontakt Interface-to-Interface, wprowadzający interfejs (sprzęg), czyli komunikowanie ludzi za pośrednictwem mediów" ". Dotyczy to również sposobu komunikowania się za pośrednictwem sztuki wirtualnej, sztuki sieci (net art), a także sposobu przedstawiania sztuki tradycyjnej w wirtualnym świecie (art in net) przez nauczycieli przedmiotów humanistycznych.

$\mathrm{Na}$ te nowe wyzwania odpowiada rządowy projekt MEN pt. „Cyfrowa szkoła”, którego celem jest rozwijanie kompetencji uczniów i nauczycieli w zakresie stosowania w edukacji technologii informacyjno-komunikacyjnych (TIK), oraz wspieranie zmiany modelu nauczania w kierunku rozwijania kreatywności, umiejętności kooperacji oraz krytycznego myślenia, w tym wyszukiwania, oceny i twórczego wykorzystywania dostępnych źródeł wiedzy. Założeniami programu są kształtowanie kompetencji społecznych i twórczych uczniów, w tym umiejętności pracy w grupie, oraz wzrost motywacji uczniów do rozwijania własnych zainteresowań. Ma to wpłynąć nie tylko na upowszechnienie indywidualizacji kształcenia, ale także ma doprowadzić do zwiększenia rozwoju kreatywności i innowacyjności nauczycieli w pracy z uczniem. Tworzenie różnych środowisk, w których będzie można udostępniać treści edukacyjne, sprawi, że nastąpi zniesienie istniejących barier w dostępie do elektronicznych zasobów edukacyjnych oraz będzie można zasięgnąć wiedzy od najlepszych specjalistów.

\footnotetext{
${ }^{2}$ COME.UW - Centrum Otwartej i Multimedialnej Edukacji Uniwersytetu Warszawskiego.

${ }^{3}$ Zawiera ono zarówno społeczeństwo informacyjne (w zakresie treści), jak i społeczeństwo sieciowe (w zakresie formy), przy czym pierwszeństwo przysługuje aspektowi formalnemu. Por.: M. McLuhan, Zrozumieć media. Przedłużenia człowieka, Warszawa 2004, s. 39-53.

${ }^{4}$ T. Goban-Klas, Cywilizacja medialna: geneza, ewolucja, eksplozja, Warszawa 2005, s. 41.

5 „Cyfrowa szkoła” - rządowy program Ministerstwa Edukacji Narodowej, przygotowany dla uczniów i nauczycieli. Realizowany w okresie od 4.04.2012 do 31.08.2013 (www.cyfrowaszkola.men. gov.pl).
} 
Aby dobrze przygotować przyszłych nauczycieli, głównym zadaniem wyższych uczelni pedagogicznych, powinno być wypracowanie modelowych przykładów zastosowania TIK w nauczaniu poszczególnych przedmiotów oraz upowszechnienie dobrych praktyk, także w zakresie nauczania o szeroko pojętej sztuce. Dlatego nie zaniedbując wartości odnoszących się do własnych doświadczeń twórczych ucznia, potrzebne jest również opracowanie innowacyjnych metod przekazywania wiedzy o sztuce. W tym przypadku należy dostosować je do nowych wymagań stawianych przed szkołą, a także do oczekiwań dzieci i młodzieży. Nauczyciel powinien dobrze orientować się w możliwościach i zasobach sieci oraz umiejętnie je wykorzystywać do przekazywania wiedzy uczniom w atrakcyjny dla nich sposób, inspirując ich tym samym do własnych działań twórczych. W tym zakresie komputer oraz Internet dają wiele możliwości.

Marshall McLuchan wskazuje, że każdorazowe pojawienie się nowego medium dokonuje zmiany, tworząc nowe środowisko. Nie jest to tylko jeszcze jeden sposób komunikowania się człowieka, jest to nowe całkowicie odmienne zjawisko na tle dotychczasowych mediów. Oznacza to, że technologie informacyjno-komunikacyjne zastosowane w szkole wymagają także zmian w samym procesie kształcenia ${ }^{6}$.

Można zatem powiedzieć że nauka o sztuce, chcąc dopasować się do nowego wymiaru rzeczywistości, w którym przeważa pokolenie Internetu, musi sięgnąć po nowe formy przekazu, korzystając z zasobów multimedialnych oraz najnowszych metod nauczania. Dzięki temu tworzy się nowy wymiar edukacji i odpowiadający mu nowy wymiar sztuki. Zależność tę można zilustrować na podstawie poniższego schematu:

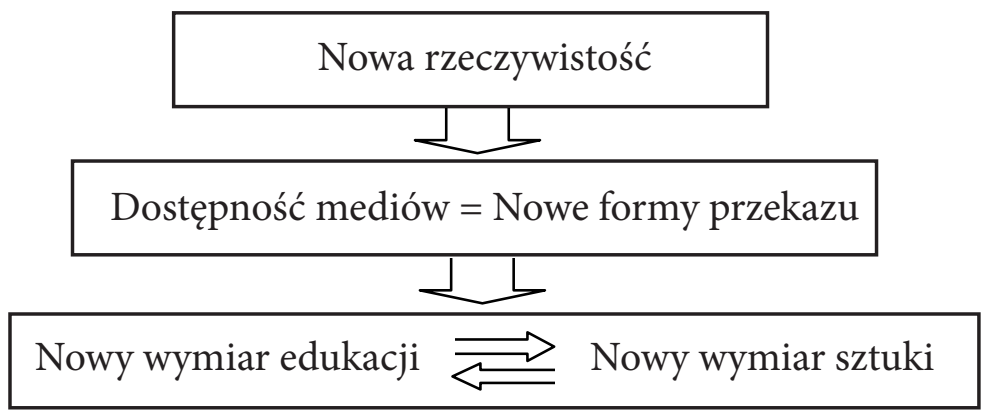

Źródło: opracowanie własne

\footnotetext{
${ }^{6}$ T. Lewowicki, B. Siemieniecki (red.), Nowe media w edukacji, Toruń 2012, s. 7.
} 
Tym nowym wymiarem sztuki staje się zatem sztuka przedstawiana wirtualnie, w której wykorzystuje się komputer oraz Internet jako instrument edukacji.

\section{Zajęcia zdalne na platformie Moodle}

Na polskim rynku znajdziemy wiele rożnych programów przeznaczonych do tworzenia kursów internetowych a także stron www. Najbardziej znany jest jednak Moodle, którego nazwa w rozwinięciu oznacza: modułowe, dynamiczne, zorientowane obiektowo środowisko nauczania (ang. Modular Object-Oriented Dynamic Learning Environment). Jest to projekt rozwojowy, zaprojektowany tak, aby wspierał strukturę społecznego konstrukcjonizmu ${ }^{7}$ w edukacji. Aplikacja ta pozwala tworzyć kursy zdalne i efektywnie nimi zarządzać.

Każdy kurs składa się z pewnej ilości informacji umieszczanych w platformie przez nauczyciela oraz także przez studentów. [...] Zazwyczaj w kursie nauczyciel stosuje kilka modułów, np. lekcja, forum, czat, quiz, zadanie. Moduły umożliwiają też systematyczne śledzenie postępów uczniów, np. moduł zadanie zwykle wymaga od studentów przesłania za pośrednictwem platformy pliku z rozwiązaniem, do którego nauczyciel będzie miał dostęp. Może więc ocenić nadesłaną pracę. Oceny są wystawiane również za pomocą platformy, uczniowie mają więc natychmiastowy podgląd swoich wyników. Do korzystania z platformy wystarcza jedynie przeglądarka internetowa ${ }^{8}$.

Każdy projekt zajęć składany do jednostki COME.UW jest pakietem modułów organizowanych w charakterze e-learningu. Studenci sami dostosowują godziny i czas nauki do swoich potrzeb oraz umiejętności. To oni decydują, w jakim stopniu chcą skorzystać z uczestnictwa w zajęciach.

Przygotowując kurs „Sztuka w sieci” na Wydziale Pedagogicznym Uniwersytetu Warszawskiego, wzięłyśmy pod rozwagę tematykę szeroko pojętej sztuki. Starając się, aby każdy kto chce pogłębić swoją wiedzę o sztuce, mógł bez uprzedniego przygotowania, przystąpić do uczestnictwa w zajęciach, dedykowałyśmy je wszystkim studentom różnych wydziałów. W ten oto sposób zajęcia ogólnouniwersyteckie zostały otwarte na tych, którzy bądź z racji studiowanego kierunku, bądź swoich prywatnych zainteresowań chcą bardziej świadomie uczestniczyć w kulturze zarówno dawnej, jak

\footnotetext{
${ }^{7}$ Zasady pojęcia społecznego konstrukcjonizmu ukazuje Seymour Papert poprzez wymienienie ośmiu wielkich idei konstrukcjonistycznych, wg tłumaczenia Andrzeja Walata (http://meritum. mscdn.pl/meritum/moduly/egzempl/7/7_8_abc.pdf; dostęp: 1.12.2013).

${ }^{8}$ Wprowadzenie do platformy edukacyjnej Moodle, 8 marca 2006 roku.
} 
i najnowszej, przekazując swoją wiedzę podopiecznym lub dalszym pokoleniom.

Doświadczenia nauczania przedmiotów związanych z szeroko pojętą sztuką pozwoliły tak ułożyć internetowy kurs „Sztuka w sieci”, aby składał się z kilkunastu lekcji, nazywanych modułami. W każdej lekcji umieszczone zostały odpowiednie materiały (graficzne i tekstowe), z którymi student powinien się zapoznać i na koniec lekcji wykonać zadanie. Do pozytywów zaliczyć należy to, że każdy student musi zapoznać się z całym materiałem, prowadzący przed wystawieniem oceny może to łatwo sprawdzić w tzw. raportach aktywności. Drugim pozytywem jest systematyczność zdobywania wiedzy - poszczególne tematy są otwierane w każdy poniedziałek, i zamykane w niedzielę późnym wieczorem. Do tego czasu student ma wykonać i przesłać zadanie, jeśli tego nie zrobi, umożliwiamy przesłanie zaległych zadań na końcu kursu, ale tu oceny za wykonane zadanie są automatycznie obniżone (studenci są o tym uprzedzeni). Do każdej oceny za wykonane zadanie dodajemy krótką recenzję, uzupełnienie lub polemikę $\mathrm{z}$ wypowiedzią studenta. Niewątpliwym mankamentem tak prowadzonych zajęć jest brak możliwości autentycznej dyskusji i wielokrotnego wypowiadania swoich sądów, tu wyjątek stanowi forum, gdzie w pełnej grupie wszystkich uczestniczących w zajęciach taką dyskusję można przeprowadzić. Ale doświadczenie to uczy, że zabranie głosu przez prowadzącego niestety kończy dyskusję.

Co prawda zadanie kursu polega na zapoznaniu studentów z zasobami sztuki w sieci i możliwością edukacyjnego ich wykorzystania w przyszłości. Aby jednak pobudzić kreatywne myślenie i ukazać moc wyrażania swojej ekspresji, na zakończenie kursu proponujemy studentom wykonanie dwóch własnych prac w jednej dowolnie wybranej dziedzinie sztuki (najczęściej fotografia, rysunek, malarstwo, ale były także wiersze i proza) i umieszczenie ich na portalu digart. Drugim twórczym zadaniem jest wykonanie kolażu - reinterpretacji współczesnej dzieła dawnego twórcy z dołączonym wyjaśnieniem, dlaczego właśnie w taki sposób praca została wykonana. W przypadku kolażu można mieć wątpliwości co do wartości tego rodzaju działań, niektórzy chętnie nazwą to dewastacją dzieł wielkich mistrzów, ale wydaje się, że jest to doskonały sposób na przybliżenie młodzieży twórczości z dawnych, często odległych, epok i nauka otwartości na to, co nowe w sztuce. 
Dzięki uczestnictwu w zajęciach studenci mają okazję nauczyć się, w jaki sposób korzystać z zasobów Internetu, aby wzbogacić i unowocześnić realizację programu m.in. z takich przedmiotów, jak: wiedza o kulturze, sztuka (plastyka, muzyka, literatura), historia, historia sztuki i architektura, język polski oraz inne. Studenci mogą poznać metody aktywizowania uczniów poprzez pracę z Internetem, a także dowiedzieć się, jak korzystać z komputera, Internetu i innych powiązanych z nimi przekaźników, aby wzbogacić realizację programów szkolnych, zapoznać się zarówno z dawnymi, jak i najnowszymi formami ekspresji artystycznej, a także dowiedzieć się, czym dla nich jest sztuka.

Naszym celem było ukazanie, że termin „sztuka” ze względu na swoją wieloznaczność i mnogość punktów widzenia, jest praktycznie niedefiniowalny. Mimo to na ogół terminem tym na co dzień określamy coś, co jest godne uznania, jest w jakiś sposób doskonałe, budzi nasz podziw. Tym określeniom odpowiada teza Władysława Tatarkiewicza, który sformułował alternatywną definicję sztuki ${ }^{9}$, starając się, aby objęła wszystkie najnowsze formy i dziedziny ludzkiego życia. Definicja ta jednak jest tak szeroka, że w odniesieniu do czasów dzisiejszych trudno jest określić, jaki intencjonalny rodzaj działania człowieka sztuką nie jest. Odkąd pojawił się Internet, niemal od razu stał się on miejscem, w którym zagościła także sztuka, i to zarówno sztuka znana i uznana, w formie zdigitalizowanej, jak i nowa sztuka sieci, czyli net art.

\section{Nowe formy upowszechniania wiedzy o sztuce}

Już wiele lat temu Stefan Szuman w swoim dziele O sztuce $i$ wychowaniu estetycznym ${ }^{10}$ wyróżnił trzy podstawowe kategorie działań edukacyjnych: udostępniania, uprzystępniania, upowszechniania.

Pierwsza kategoria dotyczy udostępniania sztuki, które polega na zadbaniu, aby dzieła stały się (w oryginale lub w dobrej reprodukcji, w dobrym wykonaniu) przedmiotem bezpośredniego oddziaływania na widzów i słuchaczy. Ten bezpośredni kontakt z określonym dziełem literackim, muzycznym czy plastycznym jest koniecznym warunkiem ich poznania, doznawania czy też przeżywania. Udostępnianie dzieła sztuki zakłada mil-

\footnotetext{
${ }^{9}$ Alternatywna definicja sztuki brzmi: „sztuka jest odtwarzaniem rzeczy, bądź konstruowaniem form, bądź wyrażaniem przeżyć - jeśli wytwór tego odtwarzania, konstruowania, wyrażania, jest zdolny zachwycać, bądź wzruszać, bądź wstrząsać”, W. Tatarkiewicz, Droga przez estetykę, Warszawa 1972, s. 35.

10 S. Szuman, O sztuce i wychowaniu estetycznym, Warszawa 1975, s. 23-26.
} 
cząco przebywanie w jego obecności i pod jego wpływem przez czas wystarczający nie tylko do pobieżnego zapoznania się z nim, lecz do poddania się jego działaniu. Aby uczeń dobrze się przygotował do odbioru sztuki, musi przebywać w otoczeniu dzieł sztuki, by je zrozumieć, przeanalizować i zapamiętać.

Druga kategoria dotyczy uprzystępniania dzieł sztuki, S. Szuman określa w ten sposób zespół tych czynności wychowawczych, za pomocą których wzbudzamy u kogoś zainteresowanie sztuką i zapotrzebowanie na nią oraz zdolność właściwego jej spostrzegania, rozumienia i przeżywania. Uprzystępnianie polega na udzielaniu odbiorcom skutecznej pomocy w odkrywaniu, poznawaniu i odczuwaniu estetycznych cech i wartości utworów artystycznych składających się na kulturę. To forma pośrednia pomiędzy dziełami kultury i sztuki a ich odbiorcami.

Trzecia kategoria dotyczy upowszechniania sztuki, związanego z jej udostępnianiem. Polega ono na zbliżaniu jej szerokim masom społeczeństwa zarówno przez udostępnianie licznych najlepszych dzieł sztuki wielu odbiorcom, jak i przez uczynienie ich przystępnymi, co powinno w rezultacie rozwinąć umiłowanie sztuki, umiejętność radowania się nią, rozumienia jej oraz zapotrzebowanie na nią u coraz szerszej rzeszy odbiorców.

Wydaje się że komputer podłączony do sieci może być bardzo przydatnym narzędziem w realizacji tych trzech „U”. To rzecz oczywista, że bezpośredni kontakt $\mathrm{z}$ dziełem sztuki jest niezastąpiony, jednakże nie zawsze, $z$ różnych przyczyn, może do niego dojść. Nie wszystkie szkoły mogą zapewnić swoim uczniom wycieczkę do najlepszych polskich muzeów czy pałaców, nie wspominając o muzeach zagranicznych, takich jak: Luwr, Ermitaż, Prado czy wiele innych. Nawet gdyby uczniowie mieli możliwość osobistego odwiedzenia tych placówek, to często liczba zwiedzających, którzy oblegają najbardziej znane dzieła, jest tak duża, że o jakiejkolwiek kontemplacji danego dzieła czy koncentracji na szczegółach nie ma mowy. Do niedawna jedyną pomocą, jaką miał do dyspozycji nauczyciel, była lepszej lub gorszej jakości reprodukcja. Obecnie sytuacja zmieniła się diametralnie, wszystkie muzea posiadające znaczące zbiory oferują na swoich stronach 
internetowych możliwość wizyty wirtualnej oraz prezentują szczegółowe informacje dotyczące posiadanych kolekcji i autorów dzieł ${ }^{11}$.

Podając przykłady kilku wybranych, najbardziej interesujących z edukacyjnego punktu widzenia stron internetowych ${ }^{12}$, na wstępie należałoby przedstawić stronę The National Gallery w Londynie ${ }^{13}$, na której prezentuje się 2300 dzieł malarskich z okresu od połowy XIII wieku do 1900 roku. $\mathrm{Na}$ stronie dostępna jest opcja wirtualnej wycieczki, co daje możliwość zorganizowania zajęć razem z uczniami. Wspólnie możemy zwiedzić wystawy, funkcja powiększania obrazu pozwala prześledzić jego szczegóły. Przy każdym obrazie są dokładne opisy, uczeń może samodzielnie w domu zapoznać się z informacjami o tematyce i autorze obrazu (opisy w bardzo przystępnym języku angielskim, co może dodatkowo motywować ucznia do jego nauki). Jest to znacznie bardziej ciekawy sposób zdobywania wiedzy o sztuce niż sucha ilustracja w podręczniku. Aktualnie dzieci potrzebują wielu bodźców z zewnątrz podczas nauki, w przeciwnym razie po prostu się nudzą. W tym przypadku nauczycielom pracującym z młodszymi dziećmi polecamy także zakładkę strony Kids in Museums ${ }^{14}$, gdzie można znaleźć ciekawe informacje o pracy $\mathrm{z}$ dziećmi. Jest to forum wymiany informacji o tym, jak rozmawiać z dziećmi o sztuce, jak prowadzić zajęcia, aby zainteresować dzieci tematem sztuki.

Interesująca jest także witryna The Metropolitan Museum of $\mathrm{Art}^{15}$, gdzie w zakładce „Metmedia” przedstawiono muzeum w interaktywny, nowoczesny sposób. Dla dzieci i młodzieży są interaktywne quizy, blog - prowadzony przez i dla nastolatków, na którym opisywane są wystawy w muzeum. Na stronie muzeum możemy obejrzeć nagrania różnego rodzaju wydarzeń poświęconych sztuce współczesnej. W zakładce „Metpublications” znajdują się publikacje wydane przez muzeum, są one dostępne w wersji on-line lub do kupienia.

Równie ciekawa z edukacyjnego punktu widzenia jest strona Luwru ${ }^{16}$. Po wejściu w zakładkę „A closer look” uzyskujemy różnego rodzaju infor-

\footnotetext{
${ }^{11}$ Warto tu wymienić: www.virtualuffizi.com, www.museodelprado.es, www.khm.at, www.rembrandthuis.nl, www.gugenheim.org, www.gallerieaccademia.org, www.musee-picasso.fr, www.brera.beniculturali.it, www.musee-orsay.fr (dostęp: 1.12.2013).

${ }^{12}$ Są to najbardziej znane i w ocenie naszych studentów - najbardziej przydatne w pracy nauczyciela witryny internetowe muzeów, które mają bardzo ciekawie przygotowane strony www.

13 The National Gallery (http://www.nationalgallery.org.uk; dostęp: 1.12.2013).

${ }^{14}$ Kids in Museums (http://kidsinmuseums.org.uk/1/discuss; dostęp: 1.12.2013).

15 The Metropolitan Museum of Art (http://www.metmuseum.org; dostęp: 1.12.2013).

${ }^{16}$ Musée du Louvre (http://www.louvre.fr; dostęp: 1.12.2013).
} 
macje o dziełach sztuki. Przy każdym dziele mamy rzeczowy opis historyczny i czysto techniczny - czytany przez lektora. Słuchając tego opisu, mamy cały czas podgląd na dane dzieło, którego aktualnie omawiane fragmenty są dla lepszego zrozumienia dodatkowo oznaczane.

Z kolei rosyjskie Muzeum Ermitaż ${ }^{17}$ w Sankt Petersburgu oferuje interesującą pod względem edukacyjnym zakładkę „Virtual Academy” przekazującą wiedzę na temat największych dzieł i autorów zgromadzonych w muzeum, które także można obejrzeć w szczegółach w zakładce „Digital Collection".

W sieci znajdziemy także stronę Google Art Project ${ }^{18}$, która początkowo umożliwiała wirtualną wizytę w 17 muzeach i galeriach sztuki na świecie. Aktualnie jest to 151 miejsc $\mathrm{z}$ całego świata, w tym placówki polskie, takie jak: Muzeum Pałacu w Wilanowie i Muzeum Sztuki w Łodzi. Każde muzeum w odpowiednio dużej rozdzielczości poleca na stronie jedno dzieło ze swojej kolekcji, które co jakiś czas jest zmieniane. Można zobaczyć tam Gwiaździstą noc van Gogha z Museum of Modern Art w Nowym Jorku, Powrót syna marnotrawnego Rembrandta $\mathrm{z}$ Ermitażu, martwą naturę hiszpańskiego kubisty Juana Grisa z Museo Reina Sofia w Madrycie, Narodziny Wenus Botticellego z Uffizi, Ambasadorów Holbeina z National Gallery w Londynie. Niektóre muzea udostępniają kilka sal, inne całość kolekcji.

Muzea można zwiedzać przy użyciu rozwiązania bazującego na StreetView, stworzonego przez Google. Użytkownik może zwiedzić 385 sal muzealnych, przechodząc płynnie z miejsca na miejsce lub przeskakując do wybranej lokalizacji. Jeśli zwiedzając, „podejdziemy” do obrazu, możemy przełączyć jego widok na dużą rozdzielczość (służy do tego ikonka +). Można zdobyć dodatkowe informacje o obrazie. Dostęp do wnętrz galerii można też uzyskać z poziomu StreetView w Google Maps. Użytkownik może również skorzystać z funkcji Create an Artwork Collection, aby zbudować osobistą kolekcję wybranych prac. Zebrano już tysiące takich zestawień.

Nowość stanowi integracja Art Project z Google+, gdzie można swoje kolekcje udostępniać, można je też pokazywać w usłudze Hangout aby $\mathrm{w}$ ten sposób prowadzić wykłady $\mathrm{z}$ historii sztuki lub organizować wirtualne wycieczki po odległych miejscach.

Google Art Project został bardzo szeroko rozreklamowany, ale nie jest jedyną stroną tego typu. Na uwagę zasługuje stworzona wcześniej przez Po-

\footnotetext{
${ }^{17}$ The State Hermitage Museum (http://www.hermitagemuseum.org; dostęp: 1.12.2013).

${ }^{18}$ Google Art Project (http://www.googleartproject.com; dostęp: 1.12.2013).
} 
laków strona Holoit ${ }^{19}$, gdzie udostępnione są panoramiczne zdjęcia setek obiektów podzielone na kategorie: sztuka (art), krajobraz, hotele, restauracje, transport, wydarzenia i wiele innych. Oprócz możliwości wirtualnej wizyty w poszczególnych obiektach (pałacach, zamkach, muzeach i galeriach), w menu jest odpowiednia zakładka, dzięki której zwiedzający uzyskuje informację o oglądanym obiekcie. Co ważne, w obu przypadkach zwiedzanie jest za darmo, a kontemplacji dzieł nie zakłócają tłumy zwiedzających.

Wiele polskich placówek muzealnych ma znakomicie przygotowane strony internetowe, niektóre specjalnie opracowane pod kątem wykorzystania w codziennej pracy nauczyciela, na wyróżnienie zasługuje z pewnością witryna Muzeum Pałacu w Wilanowie ${ }^{20}$, szczególnie dwie zakładki „pasaż wiedzy” i „przestrzeń edukacyjna”.

Innym bardzo ważnym miejscem do edukacyjnego wykorzystania na lekcjach przedmiotów artystycznych są strony bibliotek, a dokładniej zdigitalizowane zbiory Biblioteki Narodowej w Warszawie ${ }^{21}$, która udostępnia na swojej witrynie w sieci historyczną fonotekę nagrań utworów Chopina. Można wysłuchać i porównać wykonania tego samego utworu przez różnych artystów oraz zapoznać się z treścią listów Chopina będących w zbiorach biblioteki. Dodatkowo, oprócz widoku cyfrowej kopii rękopisu, jego treść jest czytana przez lektora.

Do niedawna brytyjska witryna internetowa British Library ${ }^{22} \mathrm{w}$ zakładce „virtual books” umożliwiała przeglądanie strona po stronie za pomocą ruchu myszy bogato ilustrowanych średniowiecznych manuskryptów, rękopisów, książek i nut. Kliknięcie na odpowiednią ikonkę dawało dostęp do informacji o przeglądanej książce i jej autorze, a w przypadku nut także usłyszenie zapisanej na oglądanej stronie muzyki. Niestety aktualnie już taka możliwość nie istnieje, można ją zakupić w postaci e-booka - trzeba stwierdzić, że taka komercjalizacja niektórych ogólnie dostępnych stron jest zjawiskiem negatywnym. Podobne, choć nie tak rozbudowane, możliwości wirtualnego oglądania najcenniejszych zbiorów możemy znaleźć w witrynie krakowskiej Biblioteki Jagiellońskiej ${ }^{23}$.

\footnotetext{
${ }^{19}$ Holoit (http://holoit.com; dostęp: 1.12.2013).

${ }^{20}$ Muzeum Pałacu w Wilanowie (http://www.wilanow-palac.art.pl; dostęp: 1.12.2013).

${ }^{21}$ Biblioteka Narodowa w Warszawie (http://www.bn.org.pl; dostęp: 1.12.2013).

22 The British Library (http://www.bl.uk; dostęp: 1.12.2013).

${ }^{23}$ Biblioteka Jagiellońska w Krakowie (http://www.bj.uj.edu.pl; dostęp: 1.12.2013).
} 


\section{Sztuka sieci $v s$ sztuka w sieci}

Internet stał się miejscem twórczości dla wielu artystów współczesnych. Aktualnie nie ma jednej definicji sztuki Internetu, przyjmuje się, że jej głównym medium jest Internet. Nie ma także precyzyjnie ustalonej terminologii dla tej sztuki, często spotyka się zamiennie używane pojęcia „sztuka Internetu”, „sztuka bazująca na Internecie”, „net art”, „szuka sieci”, „web art”.

Net art, czyli sztuka sieci, jest zjawiskiem stosunkowo nowym, forma tej sztuki, jak i jej krąg środowiskowy podlegają nieustannym dynamicznym zmianom. Rozwój tego rodzaju sztuki, jej poszukiwania zależne są od postępu technologii informatycznych. Artyści tworzący net art zaczynają często od eksperymentu artystycznego czy poszukiwań estetycznych i starają się stworzyć alternatywną ogólnodostępną przestrzeń ekspresji niezależną od istniejącego establishmentu sztuki.

Rozwój tej dziedziny sztuki jest związany z wielotorowymi poszukiwaniami estetycznymi, eksperymentami artystycznymi w sensie formalnym, z marzeniami o stworzeniu alternatywnych przestrzeni ekspresji niezależnych od establishmentu sztuki tradycyjnej. Środowisko net art rozwija się wokół wielu placówek, grup, indywidualności, a także imprez, konferencji, festiwali on-line, wirtualnych galerii oraz takich prestiżowych imprez, jak Documenta czy Biennale w Wenecji.

Otwartość cyberprzestrzeni i, co za tym idzie, możliwość opublikowania tam czegokolwiek przez kogokolwiek, stanowi czasem problem dla nauczyciela, ale staje się również cennym źródłem dla ucznia, studenta. Publikacje obejmują manifesty indywidualnych artystów, teksty krytyczne, kuratorskie oraz informacje o imprezach związanych z net art, eseje akademickie, elektroniczne informatory, archiwa on-line itp ${ }^{24}$. Informacje te można również znaleźć w muzeach i galeriach sztuki nowoczesnejej.

Artyści net art często tworzą prace społecznie zaangażowane. Przykładem swoistego aktywizmu społecznego w obronie środowiska naturalnego jest przedsięwzięcie „Nec ecotonoha”26, które polega na wspólnym projektowaniu wirtualnych drzew. Biorąc w nim udział, przyczyniamy się do walki z globalnym ociepleniem w realnym świecie. W miarę dodawania wirtualnych liści do drzewa sadzone są rzeczywiste drzewa.

\footnotetext{
${ }^{24}$ Strony publikujące teksty artystów i kuratorów, informacje o imprezach i festiwalach net-artowych: http://www.aec.at, http://www.turbulence.org, http://adaweb.walkerart.org (dostęp: 1.12.2013).

${ }^{25}$ Są to m.in.: http://walkerart.org/gallery9/, http://media.macm.qc.ca/homea.htm, http://www.zkm.de (dostęp: 1.12.2013).

${ }^{26} \mathrm{Nec}$ ecotonoha (http://www.thefwa.com/site/nec-ecotonoha; dostęp: 1.12.2013).
} 
W dziedzinie net art na szczególną uwagę zasługują dokonania nieistniejącej już polskiej grupy „Twożywo” ${ }^{27}$. Prace grupy cechowały się dużą dozą zaangażowania w społeczne problemy. Grupa inspirowała się konstruktywizmem, popartem, futuryzmem, reklamą, poezją konkretną. Swoje prace $\mathrm{z}$ zasady prezentowała $\mathrm{w}$ przestrzeni publicznej, by $\mathrm{z}$ przekazem móc dotrzeć do jak najszerszej grupy odbiorców. Członkowie grupy tworzyli plakaty, billboardy, murale, ilustracje prasowe. Rozwijali intensywnie również projekty internetowe (m.in. „Kapitan Europa” - seria przewrotnych animacji krytykujących niepohamowaną konsumpcję, domagająca się aktywności od odbiorcy), traktując Internet jako równie istotny fragment przestrzeni publicznej co miejska ulica.

Polską wirtualną ogólnodostępną galerią jest portal Digart.pl ${ }^{28}$. Jest to serwis internetowy adresowany do twórców sztuki cyfrowej, czyli do twórców net art, który obejmuje różnorodne dziedziny sztuki: od grafik, rysunków, poprzez fotografie, malarstwo, po projekty stron internetowych i wiele innych. Praktycznie każdy może tam pokazać wszystkim swoje prace, umieszczając je również w kategoriach tekstowych, takich jak poezja czy proza. Można także zapoznać się z oceną innych osób na temat swojej twórczości, otrzymując informację zwrotną z opinią o danej pracy.

\section{Zakończenie}

Podsumowując rozważania na temat przygotowania nauczycieli do korzystania z sieci i sposobów wykorzystywania Internetu, należałoby nadmienić, że stworzenie dobrych warunków do prowadzenia zajęć dydaktycznych oraz wyposażenie pracowni w odpowiednie media i środki dydaktyczne (interaktywność) to już za mało. Niezbędne staje się właściwe zestawienie metod, formy i środków dydaktycznych, również tych uwzględniających działania e-learningowe, które mogą znacznie podnieść efekty nauczania.

Najpierw trzeba zatem stworzyć odpowiednie warunki do kształcenia nauczycieli, wyposażyć ich w odpowiednią wiedzę i umiejętności, prowadzić działania charakteryzujące się wszelką twórczością, aby wreszcie mogli oni poznać i zrozumieć sztukę, czyli posiąść wiedzę o sztuce dawnej i nauczyć się odczytywać treści sztuki nowej. Wtedy można mówić o pełnym przygotowaniu nauczyciela do przekazywania wiedzy o sztuce.

\footnotetext{
27 Grupa Twożywo (http://www.twozywo.art.pl; dostęp: 1.12.2013).

${ }^{28}$ Digart - Digital Art Community (http://www.digart.pl; dostęp: 1.12.2013).
} 
Przygotować należy także instytucje kulturalno-oświatowe uprzystępniające sztukę, które powinny bardziej skupić się na sposobie, w jaki uczą, co zaowocuje nie tylko większym zainteresowaniem sztuką, ale także wzrotem kreatywności, indywidualności uczniów i zwiększoną aktywnością uczestników. Dzięki temu sztuka stanie się bardziej widoczna w naszej codziennej rzeczywistości, a my będziemy w stanie ją zauważyć, a co więcej - docenić.

Co prawda beneficjentami projektu „Cyfrowa szkoła” są nauczyciele i uczniowie klas IV-VI szkół podstawowych i ogólnokształcących szkół muzycznych I stopnia oraz uczniowie klas I-III tych szkół, ale należałoby rozszerzyć zakres programu na pozostałe etapy wychowania. Pierwszym krokiem jest nauczanie sztuki poprzez moodle, reszta zależy od samego nauczającego, wiedza jest wszędzie, należy ją tylko umiejętnie wykorzystać.

\section{Bibliografia}

Banach C., Cechy osobowościowe nauczyciela, „Nowa Szkoła” 1995, nr 3.

Goban-Klas T., Cywilizacja medialna: geneza, ewolucja, eksplozja, Warszawa 2005.

Lewowicki T., Siemieniecki B. (red.), Nowe media w edukacji, Toruń 2012.

McLuhan M., Zrozumieć media. Przedłużenia człowieka, Warszawa 2004.

Mistewicz E., Witamy w Nowych Mediach, „Nowe Media” 2012, nr 1.

Szuman S., O sztuce i wychowaniu estetycznym, Warszawa 1975.

Tatarkiewicz W., Droga przez estetyke, Warszawa 1972. 